
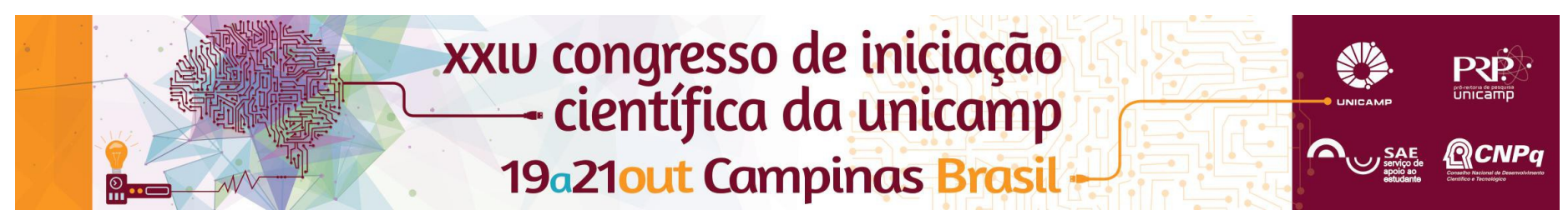

\title{
Software para transcrição e edição de partituras impressas para o sistema Braille
}

\author{
Ester Cristina Alves Maximo, Vilson Zattera, José Fornari
}

\begin{abstract}
Resumo
A acessibilidade à música pelo deficiente visual continua sendo um desafio. Este projeto trata da utilização de recursos tecnológicos para a promoção da acessibilidade computacional à pessoas com deficiência visual. Estudou-se aqui os softwares de música Lime Allowed, o editor de textos Microsoft Word, o leitor de tela de código-livre NVDA (Non Visual Desktop Access) e ferramentas de scanners com recurso OCR (Optical Character Recognition). Estas foram utilizadas para a edição e acesso (via leitor de tela) a textos e partituras musicais em Musicografia Braille.
\end{abstract}

\section{Palavras-chave:}

Deficiência visual, Notação musical, Musicografia Braille.

\section{Introdução}

Lime Allowed é uma ferramenta de software que permite editar, ler e escrever notação musical impressa e digital para o sistema acessível ao músico com deficiência visual, a Musicografia Braille. Este software proporciona ao musico com deficiência visual acesso a vários recursos de edição de partituras, tais como: 1) escrita, 2) análise, 3) edição, Isto permite que partituras musicais sejam acessadas via leitores de telas (softwares capazes de transformar o texto em áudio, através de um sintetizador de voz). Deste modo o músico com deficiência visual pode analisa-las, corrigi-las e posteriormente envia-las para outro software; o GOODFEEL Braille Music Translator que converte a partitura em arquivo de texto (em formato txt) para ser impressa em Braille. O NVDA é um software leitor de tela e bastante conhecido, que ajuda o deficiente visual na hora de sua leitura, através do computador, fornecendo a este musico pistas verbais e musicais que facilitam a utilização independente do Lime Allowed, de forma mais produtiva, dando assim oportunidade ao deficiente visual de operar autonomamente esta ferramenta de Software. O Lime Allowed funciona como um produto autônomo e interage com um software tradutor GOODFEEL, que é um conversor para a Musicografia Braille, que transcreve e torna possível que esta seja impressa em Braille.

\section{Resultados e Discussão}

O trabalho aqui apresentado foi desenvolvido através da tradução, leitura e pesquisa dos manuais destes softwares, onde foram explorados os atalhos de teclado, já que não é possível para as pessoas com deficiência visual o uso do mouse do computador. É assim importante contar com a presença de uma pessoa vidente (com visão normal) para acompanhar o músico com deficiência visual, na manipulação destas ferramentas de software, pois o leitor de telas nem sempre fornece todas as informações necessárias para a execução das tarefas referente ao acesso à partitura musical.
Mesmo levando-se em conta o fato de que a aluna que trabalhou neste projeto não possuir conhecimento prévio com partituras e notação musical, o seu desenvolvimento com este software superou as expectativas dos coordenadores, ainda mais tendo-se em conta o fato de que alguns atalhos não funcionaram conforme o manual do software explicava, o que fez com que a leitura, a escrita e a pronuncia do leitor de telas permanecesse no idioma Inglês.

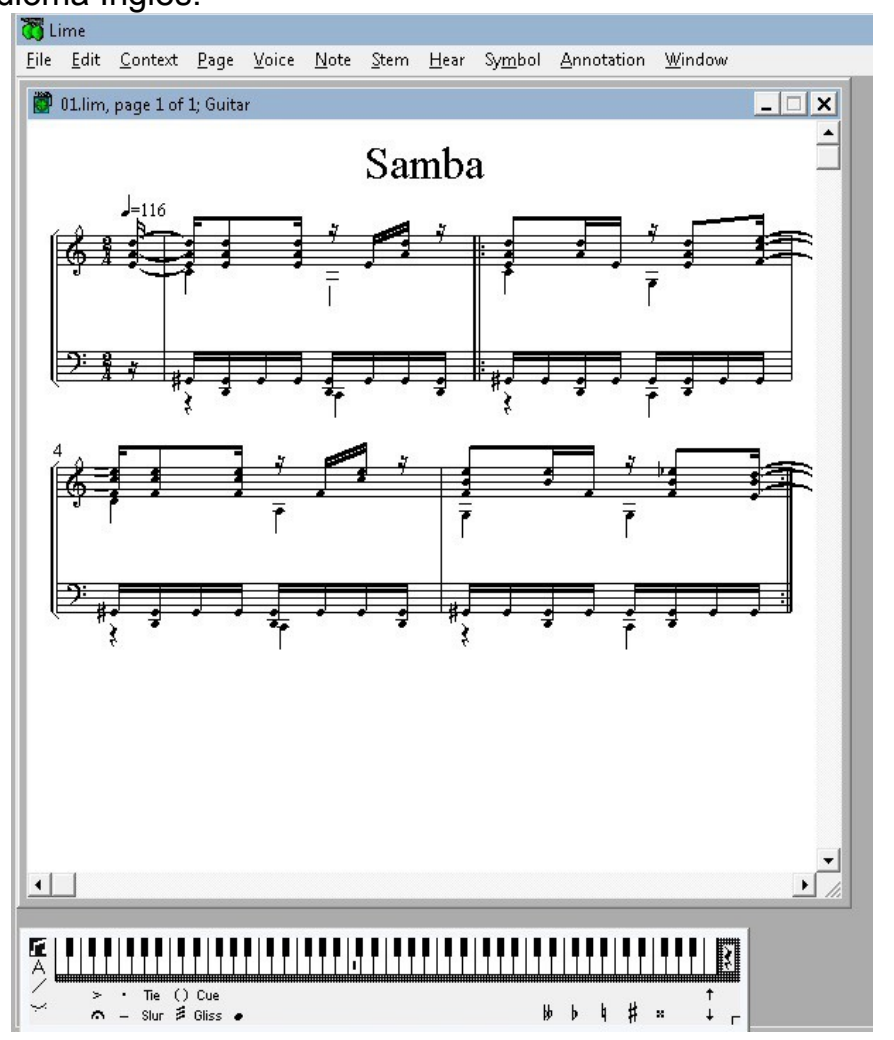

Figura 1. Imagem de uma partitura no Lime Allowed.

\section{Conclusão}

Este projeto tratou do estudo de uma nova forma para promover o acesso do músico com deficiência visual à música, através de diversos recursos computacionais, tais como os leitores de tela, scanner com OCR e ferramentas de softwares para a Musicografia Braille. 